\title{
Indications of the presence of Middle Neolithic pottery kilns at Magoula Imvrou Pigadi, SW Thessaly, Greece
}

\author{
Nina Kyparissi-Apostolika \\ Honorary Director of the Ephoreia of Palaeoanthropology and Speleology of South Greece, \\ Ministry of Culture and Tourism, Athens, GR \\ nkyparissi@hotmail.com
}

\begin{abstract}
Red hot deposits were uncovered on the western edge of a Middle Neolithic settlement. With the extension of the excavation, a wide space of about $10 \mathrm{~m}^{2}$, confined between two clay walls, very much affected by high temperatures, was uncovered. A number of vases almost totally complete after their preservation and a clay model of a kiln were unearthed. Additionally, clay remains of constructions were uncovered. The whole context suggests an area where pottery firing activities took place. The possibility that these kilns could have worked as a specialized craft workshop for other settlements in the area is discussed.
\end{abstract}

IZVLEČEK - Na zahodnem robu naselbine iz obdobja srednjega neolitika so bili odkriti rdeče žgani depoziti. $Z$ razširitvijo izkopavanj je bila odkrita površina ok. $10 \mathrm{~m}^{2}$, ki je bila zamejena z dvema glinenima zidovoma, na katerih so bile vidne sledi visokih temperatur. Izkopanih je bilo veliko število vaz, ki so bile skoraj v celoti ohranjene, in glineni model peči. Poleg tega so bili odkriti glineni ostanki konstrukcije. Celotni kontekst kaže, da gre za lončarsko peč. V članku razpravljam o možnosti, da so te peči služile specializirani obrtniški delavnici za ostale naselbine v okolici.

KEY WORDS - Middle Neolithic; Thessaly; pottery kilns; craft specialization

\section{Introduction}

The Magoula (Tell) Imvrou Pigadi is located on the southwestern edge of the Thessalic plain, which is under the administration of Phthiotis, Neo Monastiri (Municipality of Domokos) and very close to the Athens-Thessaloniki railway line $(1200 \mathrm{~m}$ south of the station at Domokos). Some other tells of the Neolithic period are visible in the vicinity of the area (Fig. 1), while numerous Neolithic settlements are located on the western Thessalian plain (Nikolaou, Firfiris 1999). Imvrou Pigadi seems to be one of the most outstanding, because of its significant height. The tell extends over $c .6000 \mathrm{~m}^{2}$, but since part of its western side was cut in the past during local road construction, we estimate that its original size would have been even larger.

The excavation started in 2002 at the top of the tell with a $5 \times 5 \mathrm{~m}$ square trench. The trench reached a depth of $c .2 .50 \mathrm{~m}$, where most of the floor was covered by structural remains attributed to walls made of mud bricks that were not well preserved. We decided that these features should be kept intact for further study, analyses etc., and therefore we could not extend the excavation into deeper layers, since the space between the structural remains was very limited. We chose to use the old western section of the tell cut by the road, which offered the possibility of a stratigraphic sequence. The section was bordered to the west by the original trench at the top of the tell, allowing us to test the thickness of the deposits. Indeed, the clearance of this $2.70 \mathrm{~m}$ wide section extended to a depth of $3.50 \mathrm{~m}$ and it was still apparent that the anthropogenic deposits went even deeper. By means of a second trench, which was placed at the road beneath the stratigraphic section, we set out to investigate the deposit at full depth. 
At $3.57 \mathrm{~m}$ (measuring 'point zero' from the top of the tell), a solid clay wall was revealed $(0.70$ to $0.80 \mathrm{~m}$ wide), which went even deeper, thus dividing the trench into two sections, north and south. From this depth onwards, the layers began to vary considerably: the northern side produced finds and layers relevant to the overlying ones, along with the characteristic presence of small carbons, while the southern side produced intense reddish burnt deposits (Fig. $2 a-b)$, from which large parts of clay slabs were unearthed. Once pieced together, they produced interesting rectangular containers $(22 \times 23 \mathrm{~cm}$ and $26 \mathrm{~cm}$ high; Fig. 3), baked masses of clay with imprints of branches

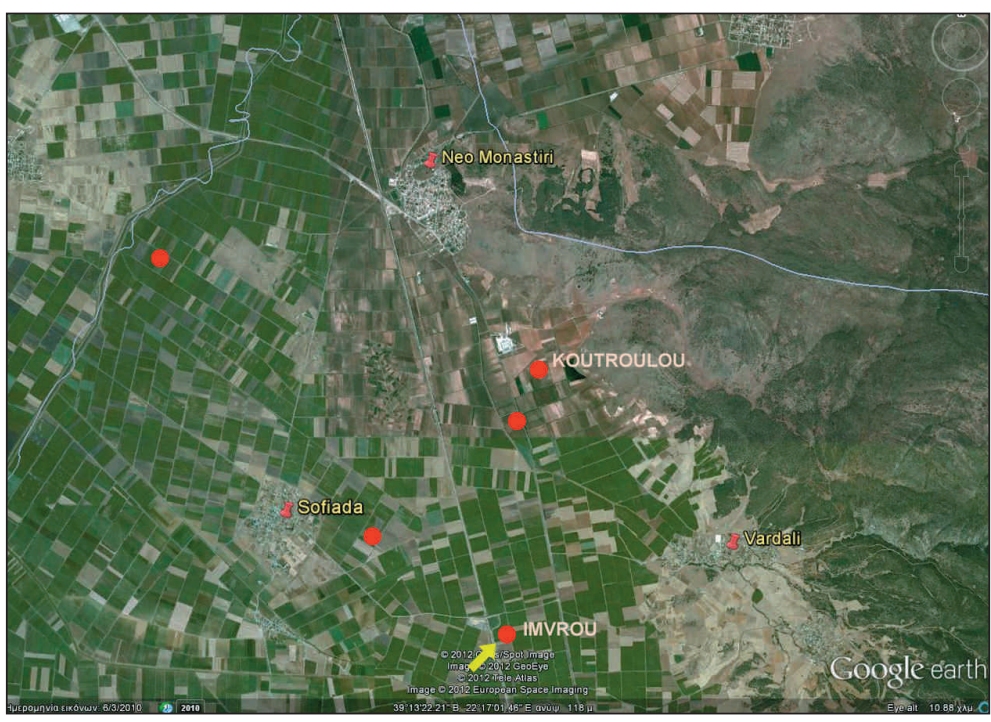

Fig. 1. Map of the area. Neolithic settlements located close to Imvrou Pigadi are marked in red. or reed on their inner surface, as well as a few figurines and tools. Furthermore, the excavation of the southern area revealed two vertical plastered clay walls, of relatively low height, forming a corner, together with a flat surface of clay at the bottom (Fig. $2 b)$. Reddish burnt deposits were present in the whole sequence, together with big pieces of carbons. The context as a whole was identified as a house interior with side walls and floor, and as a layer of destruction. Fortunately, our scientific curiosity did not end there. These burned deposits seemed to extend towards the south and west, i.e. towards the road.

We therefore expanded the trench in the direction of the burned deposits (south and west). Due to financial constraints, which did not allow for long excavation periods, it took some time to reach the corresponding depth in the expanded trench. However, when we reached that depth (in 2009), the same intense characteristics of burning were confirmed over almost the whole area, indicating the same use. These fired deposits produced pottery fragments that were later assembled to form several complete pots (Figs. 4-5) (nine vessels in total) that seemed to be unused. A complete clay model representing a kiln (Fig. 6) suggested the idea for the use of the space and an explanation for the intense red deposits. A similar interpretation of the presence of these deposits was offered by our colleague, geologist Panagiotis Karkanas, based on geological observations (and with no knowledge of the existence of the kiln model as yet): the strength and extension of the combustion had uniformly affected structures, in many cases one was on top of the other; furthermore, the characteristics of the deposits outside the burned surface formed multiple layers of ash, as if they had been thrown and left there after the clearing of a fire with the aim of reusing the space for a new fire (Fig. 7).

As the excavation continued, it became apparent that the clay wall extended to the west by a total length of $4.45 \mathrm{~m}$ (Fig. 8), although it could have extended further, beyond the boundaries of the trench and under the asphalt (since the trench was located at the ditch adjacent to the road). This clay wall might also extend to the east, under the unexcavated deposits of the tell. In 2010, we reached the desired depth over the entire area of the extended trench and joined it with the initial deposit with the same characteristics uncovered south of the solid clay wall of the trench in 2003. It became obvious that we were indeed at the core of more than one pottery kiln (Fig. 9), inside which, we believe, would be even more 'just' finished and unused vessels in situ. But, of course, there would have been no point in ruining the burnt deposit, risking the destruction of part of the kilns, in order to find a few more vessels. This project requires time and caution, since it must be ensured that the structures of the kilns are not destroyed.

More interesting evidence was revealed in the form of another compact clay wall, parallel to the first, at a distance of $5 \mathrm{~m}$ to the south, limiting the intense fire deposits between the two (Fig. 9 top). The burnt area, defined by these two parallel walls on the one side and by the two vertical and parallel sections of the trench from the other, create a rectangular space of about $10 \mathrm{~m}^{2}$ (we estimate that in total it would 
be more extensive, since part of it continues to the west, under the road, as already mentioned). That this use of space is confined between the two clay walls is confirmed by the fact that in 2011 in the deposit at the south edge of the trench, beyond the south (second) wall, only ash residues with no ceramic or other finds (indicative of domestic or other use) were uncovered, with the exception of a few small random sherds. However, outside the second wall and at a distance of just $0.20-0.30 \mathrm{~m}$, another clay wall was unearthed, about $0.40-0.60 \mathrm{~m}$ wide and affected by high fire temperatures. It is estimated that this new wall might be a boundary of another similar compound of kilns that extends south of the first one. In order to investigate this hypothesis a significant quantity of archaeological deposits has to be excavated. For the time being, it can only be tested with the use of drilling 'carrots'.

\section{Description of the kilns and discussion}

As soon as the structure became apparent, we believed it was just one kiln. However, as we continued removing the soil that had protected it, more surfaces were revealed: flat, angular, plastered, sometimes inclined like big jars turned to the side (Figs. $9 a-b, 10)$, mud bricks and also the usual surfaces of baked clay, with imprints of branches or reed on their inner side. We then began to realize that this was more than one kiln. It became obvious that the plastered clay structural remains that we had found at the beginning of the excavation (2003) must have been part of a construction like this. These remains share the same characteristics and were identified at the time as house walls. We had then actually entered a kiln the roof of which has not been preserved; and the clay slabs that were found were the sides of a rectangular vessel (Fig. 3b). That is why they had not been destroyed - as they would have been in a construction layer as originally estimated but were preserved in a good condition and could be totally restored. Similar vessels of the same size were later found close to the kilns.

Since the preserved parts of these constructions attributed to kilns seem to be in situ or partly fallen to the side, we believe that they constitute the base and sides of the kilns. The clay surfaces with branch imprints on the inner side (Fig. 11) probably formed part of the roofs of the kilns, which would not have been stable, and would have been replaced each time they were damaged, or when a bigger usable space was required, raising the roof higher. The hy- pothesis for the reconstruction of the kilns is based on the kiln model itself (Fig. 6), where a flat surface is used as the floor of the kiln (in the model, it is based on four legs not necessarily identical to the real kilns), and a convex surface as a roof with three openings, one at the entrance and two at the sides for the smoke to escape. Alternatively, the clay items with branch imprints could have served to conceal these openings when necessary, in order to regulate the temperature. Perhaps when the preservation program for all the surfaces is approved, assumptions like this can be confirmed.

The almost fully restored vessels mentioned earlier (Figs. 4-5) were collected over the whole of the southwest trench area. They were the first serious indication of the special function of the space as a kiln. All these vessels are monochrome with matt surface indicating that the pots were fired in monochrome and some were later painted or polished. Interestingly, the burnt deposits contained several deer horns, and probably of some other species, a material that has yet to be studied in detail. Their context does not point to ceremonial use, as in later periods, but this assumption needs further investigation (they could even be used as fuel). However, a quantity of burnt concentrated seeds (wheat, barley, possibly oat, and in lesser quantity, pulses: lentil, bitter vetch, common pea) was also collected from the area of the kilns in order to investigate whether cooking activities occurred parallel to the firing of pottery.

Apart from the vessels mentioned earlier, the pottery from the first trench at the top of the tell and from the west section and the deposits out of the burnt area at the second trench is characterised by a great variety of painted decorative styles, in which the dominant styles are the so-called A3b style (red or orange on white/brown on white) or conversely, white lines on red or brown, a variation of the $\mathrm{A} 3 \mathrm{a}$ style (Kyparissi-Apostolika 2006.609-610; 2009). Scraped ware, sometimes in combination with painted decoration on the other side, is also observed, while the decorative motifs of the rich painted pottery include compact triangles, rhombus, crossed lines and steps (Figs. 12-13). These motifs are common throughout Thessaly in the Middle Neolithic (Wace, Thompson 1912.13-24), but we do not know where they were made, if they were made in each settlement, or if they were transferred via secondhand exchanges to several destinations. Anthropomorphic figurines of several types have also been found at this site (Fig. 14). 
A reasonable question that arises is whether the kilns served the needs of this particular settlement, or even of others, as a kind of craft specialization, given that there are numerous other, perhaps smaller settlements in the vicinity, such as Magoula Koutroulou at a distance of $c .3 \mathrm{~km}$, where no similar space has been located, although it has been extensively excavated (Kyparissi-Apostolika 2006; Kyparissi-Apostolika, Hamilakis 2012; Hamilakis, Kyparissi-Apostolika 2012). Thermal constructions of the Late Neolithic have been found at Makryhori near Larissa ( $G$. Toufexis, personal communication) and at Makriyalos, Pieria, also of the Late Neolithic, linked by the excavator on the basis of cooking procedures (Pappa 2008.197), while the oven inside the model of the interior of a house found at Platia Magoula Zarkou (Fig. 15) has a similar shape (Gallis 1985). Of the same structural and functional logic are kilns of much later periods, such as a Mycenean example found at Masholouri of Karditsa (Vaiopoulou 2012) and one found east of the village of Orfana in 1992 (Rondiri 1999) (Fig. 16) from the Classical period (and, of course, many other examples from later periods up until the present).

No other kiln models from the Greek Neolithic are known. However, a comparison could be drawn with a clay object from the Cucuteni culture (Poduri-Dealul Ghindary, 4750-4500 BC Precucuteni III), which was exhibited at the exhibition The Lost world of Old Europe: the Danube Valley 5000-3500 BC at the Goulandri Museum in Athens in 2010, where it was generally referred to as an architectural model (Fig. 17) (Lazarovici 2010; see also Lazarovici 2002).

At this point, it should be noted that ${ }^{14} \mathrm{C}$ dating of older samples taken from three depths $(1.66 \mathrm{~m}$ from section 1 at the top of the tell; $4.70 \mathrm{~m}$ from the south area; $6.20 \mathrm{~m}$ from the north area-section 2 of the ditch excavation in 2003) produced ages that range from $6962 \pm 25$ BP (DEM-1434), 6923 \pm 36 BP (DEM$1435)$ and $6567 \pm 40 \mathrm{BP}$ (DEM-1402). This chronological uniformity was not confirmed by the pottery, where the evolution between the upper and lower layers was obvious. This parameter was noted in the first publication of the site (Kyparissi-Apostolika 2009). If we assume that the area under consideration was indeed a complex of kiln constructions for large-scale pottery production, then I believe we can explain why the ${ }^{14} \mathrm{C}$ ages were similar in the upper and lower layers (given that the second dated sample was taken from the southern side of the excavation of 2003, namely where the red-hot deposits were first discovered): it seems that the kilns were installed at the western edge of the settlement and used throughout the Middle Neolithic, and not only in the deeper layers with which they appear to correspond statigraphically.

The Middle Neolithic has proved to be the richest period in prehistoric Thessaly, and the peak of a long continuous tradition that has its origins in the Early Neolithic (Theocharis 1973). This notion has come to replace older beliefs, based on stylistic differentiations, which treated the two periods as distinct. The finds from Imvrou Pigadi and especially the presence of kilns in such an early phase support this valuation.

For the time being, the excavation of the kilns has been halted in order to evaluate as thoroughly as possible the structural remains. Although they have not been preserved as solid constructions, they can provide important information, which can significantly help restore their original form and function. A lot of work has still to be done: a careful and thorough cleaning of the structural remains in order to uncover as much as possible of their original form, rigorous planning and photographing during the several stages of uncovering, conservation, and finally an interpretation of the formation of their form and function. Additionally, analyses of the burnt deposits and temperatures to which they were exposed should help us understand the nature of the functional areas.

In conclusion, I would like to stress that our insightful decision to further explore the horizontal stratigraphic differences in the initial trench led to the discovery of such an important find, which would otherwise have passed in the bibliography as yet another destruction layer in a house. 


\section{References}

Gallis K. 1985. A Late Neolithic foundation offering from Thessaly. Antiquity 59: 20-24.

Hamilakis Y., Kyparissi-Apostolika N. 2012. Koutroulou Magoula in central Greece: from the Neolithic to the present. Online http://antiquity.ac.uk/projgall/ hamilakis 333/.

Kyparissi-Apostolika N. 2006. Koutroulou Magoula sto Neo Monastiri (voreia Phthiotis): I apokalypsi mias neas, "astikis" architectonikis Neolithikis engatastasis. Proceedings of the $1^{\text {st }}$ Scientific Meeting AETHSE 1, Volos 27.2-2.3.2003: 607-617.

2009. Magoula Imvrou Pigadi at Neo Monastiri (one more Middle Neolithic settlement at the north borders of Phthiotis). Proceedings of the $3^{\text {rd }}$ Scientific Meeting AETHSE 3, Volos 16-13.3. 2006: 839-852. (in Greek with an English summary)

Kyparissi-Apostolika N., Hamilakis Y. 2012. Archaeological and ethnographic research at the site of Koutroulou Magoula in Phthiotis, 2009-2011 (oral presentation). $4^{\text {th }}$ Scientific Meeting AETHSE 4, Volos 15-18.3.2012.

Lazarovici C.-M. 2002. Sanctuarele Precucuteni-Cucuteni. Arheologia Moldovei 25: 47-67.

2010. Cucuteni Ceramics: Technology, Typology, Evolution and Aesthetics. In D. W. Antony, J. Y. Chi (eds), The Lost World of Old Europe, The Da- nube Valley, 5000-3500 BC. The Institute for the Study of the Ancient World at New York University. Princeton University Press, Princeton and Oxford: 132, Figs. 6-9.

Nikolaou E. and Firfiris A. 1999. Apo tous Neolithikous oikismous tis dytikis thessalikis pediadas. Praktika A' Istorikou Synedriou Palama, 2-3 July 1994: 53-103.

Pappa M. 2008. Organosi tou horou kai oikistika stoiheia stous Neolithikous oikismous tis Makedonias. Unpublished $\mathrm{PhD}$ thesis. University of Thessaloniki. Thessaloniki. Online http://phdtheses.ekt.gr/ eadd/browse? type=subject

Rondiri V. 1999. Neoteres anaskafikes erevnes sta Orfana Nomou Karditsas. Praktika A' Istorikou Synedriou Palama, 2-3 July 1994.

Theocharis D. R. 1973. Neolithic Greece, O Neolithikos politismos. National Bank of Greece. Athens: 17120.

Vaiopoulou M. 2012. Oikismos tis metavatikis periodou apo tin Mesoelladiki III stin Ysteri epohi tou Halkou stis "Rahes" Masholouriou: mia proti parousiasi. (Oral presentation) $4^{\text {th }}$ Scientific Meeting AETHSE 4, Volos 15-18.3.2012.

Wace A. J. B., Thompson M. S. 1912. Prehistoric Thessaly. Cambridge University Press. Cambridge. 

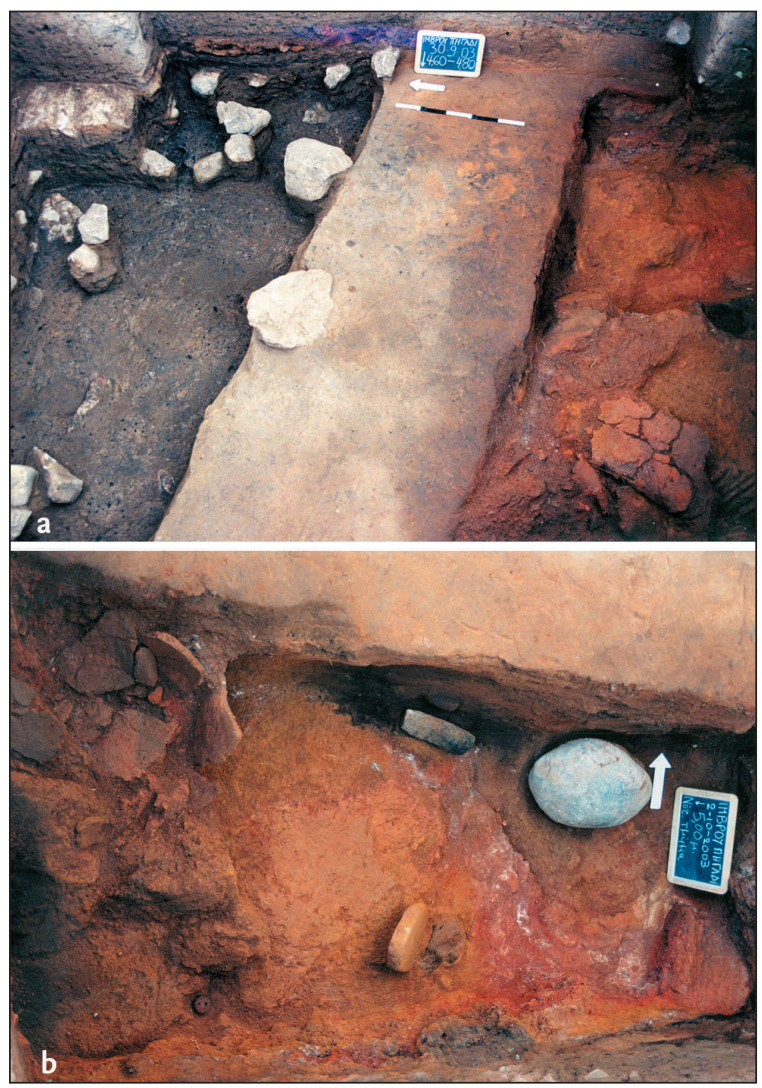

Fig. 2a. The clay wall that separates the deposits: on the right (south) side are burnt deposits and on the left (north) ashy deposits with carbons.

$2 b$. The trench with burnt deposits when they were first uncovered in 2003. Clay slabs, a floor surface and some stones are visible.



Fig. 4. A large, almost complete jar after restoration. It was unearthed from the burnt deposits.
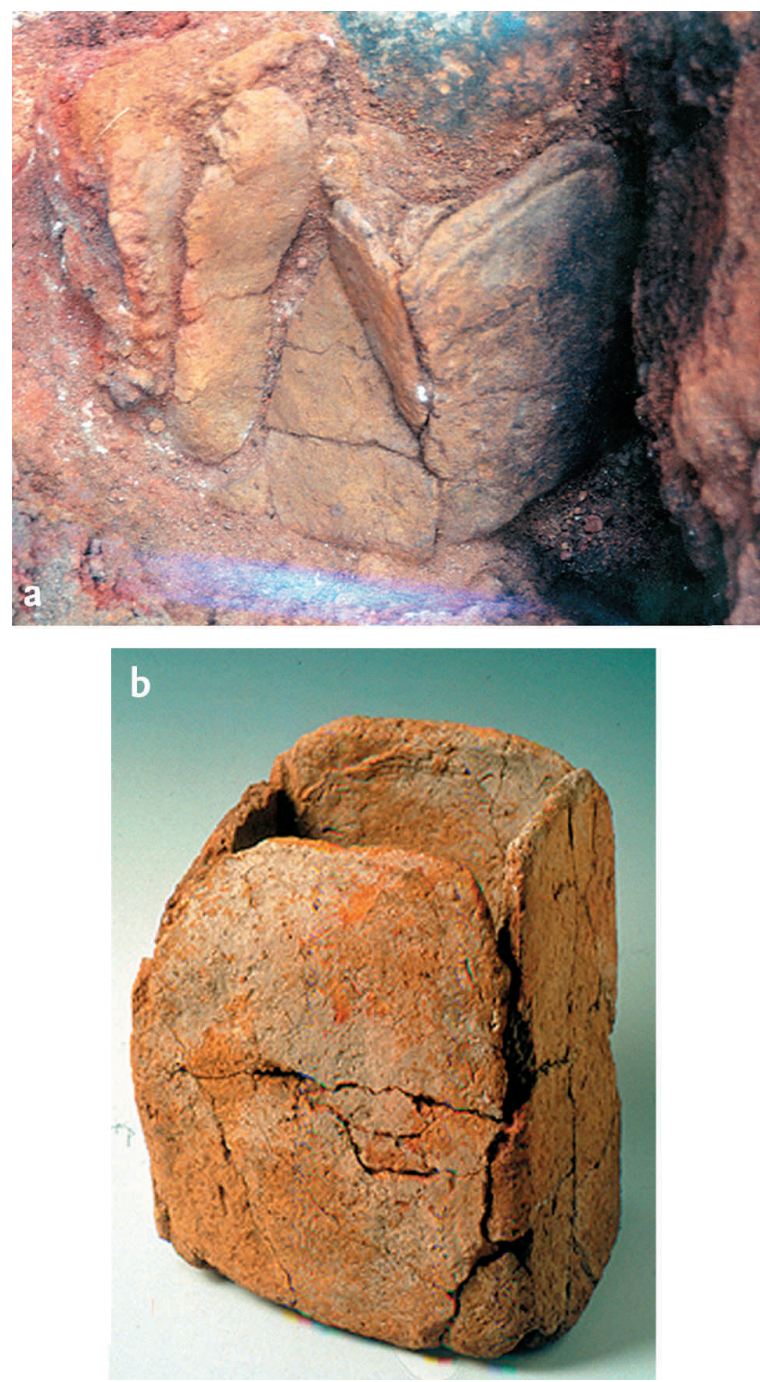

Fig. 3a. Clay slabs as they were found during the excavation. 3b. The same slabs after restoration, producing a rectangular vessel. 
Fig. 5. Clay vessels, almost complete, unearthed from the burnt deposits.
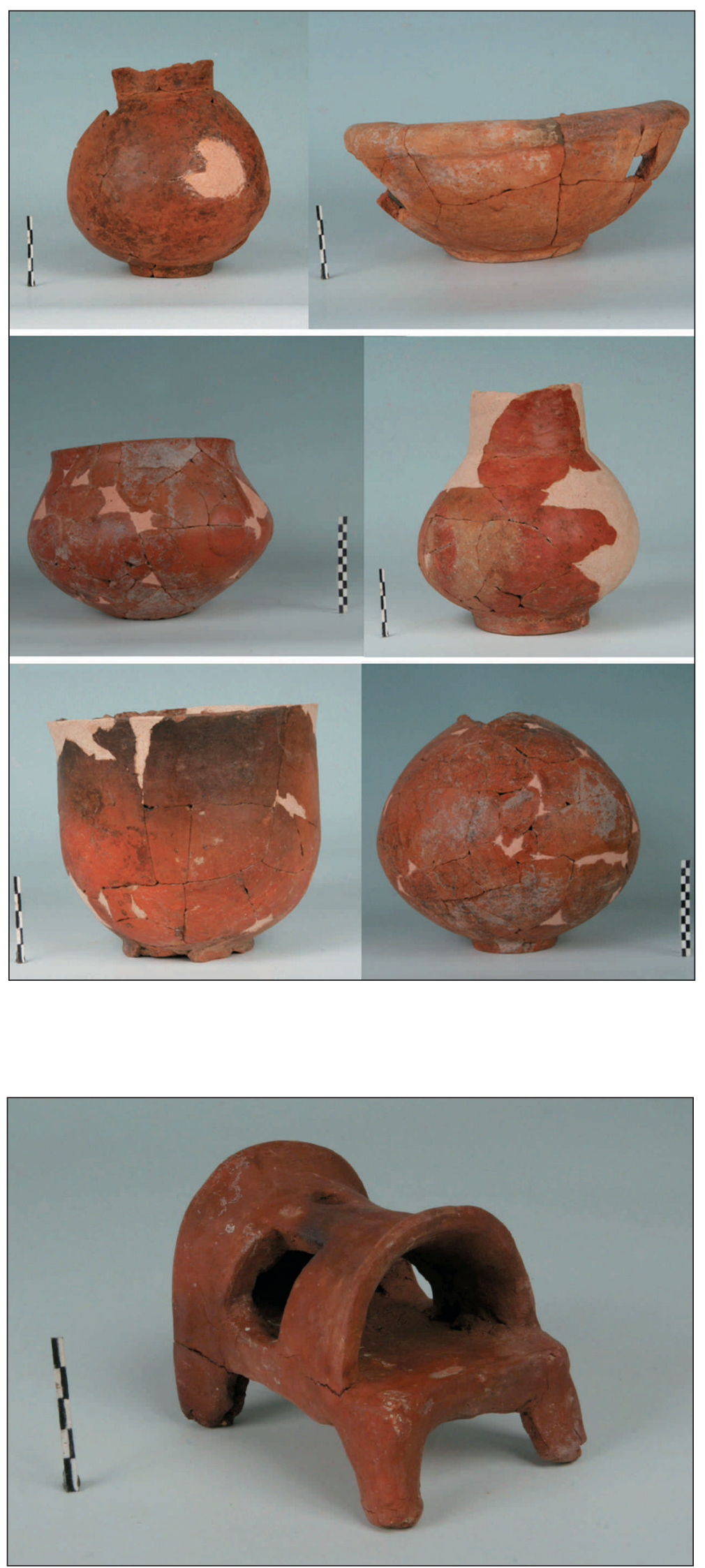

Fig. 6. A clay kiln model that probably coincides with the kilns at the site. It was found together with the vessels in figure 5 among the burnt deposits. 


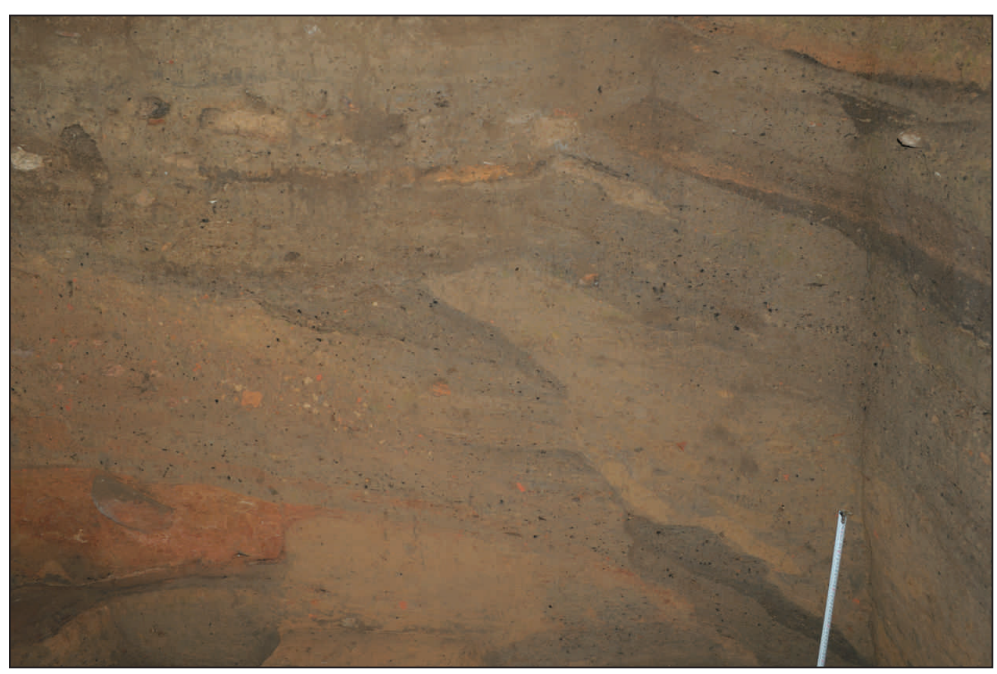

Fig. 7. The ashy layers outside of the burnt deposits with many small carbon fragments.

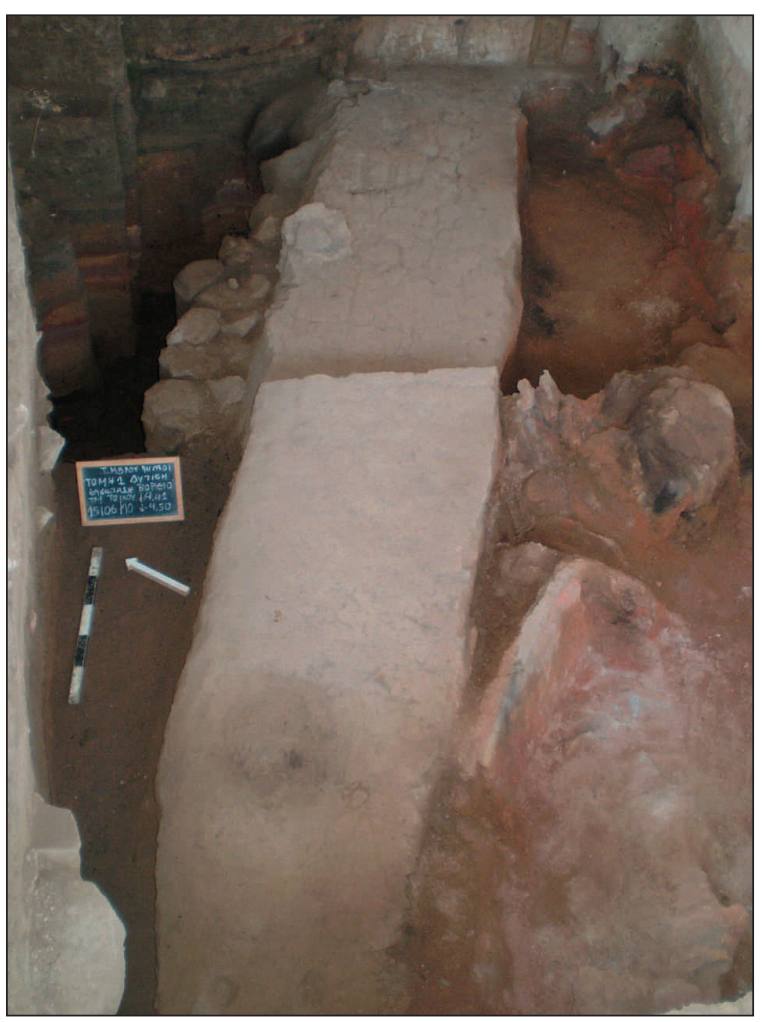

Fig. 8. The first clay wall to the north after the extension of the excavations. It is $4.45 \mathrm{~m}$ long.
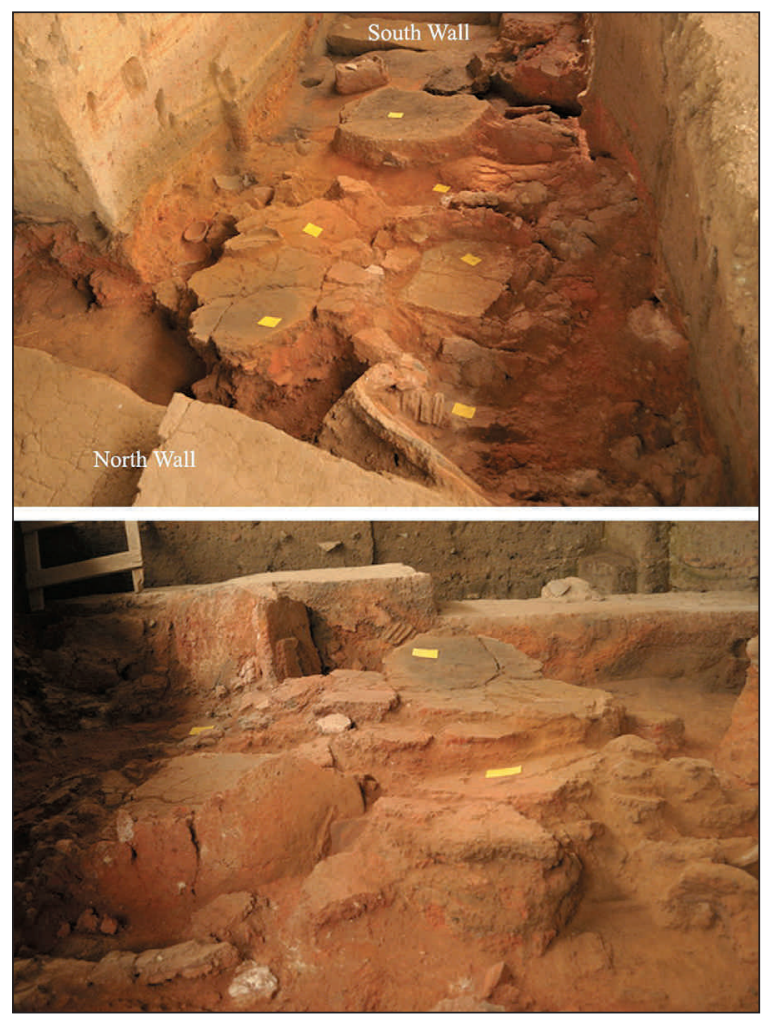

Fig. 9. The remains of the structures attributed to kilns, which are defined between two clay walls, north and south. 


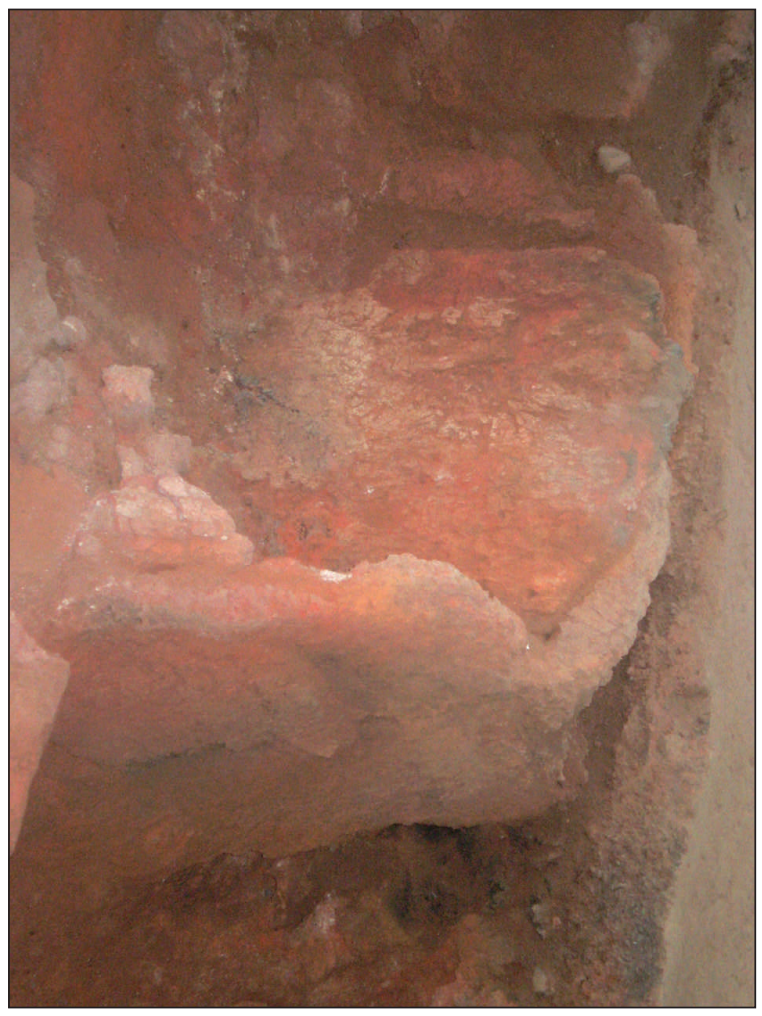

Fig. 10. Detailed picture of one of the kiln structures.



Fig. 12. A large piece of a vessel painted in A3b decoration.

Fig. 13. Parts of decorated vessels in A3b (the upper one) and in A3a (the two others).



Fig. 11. Details of the excavation, with clay slabs and branch imprints on clay surfaces.

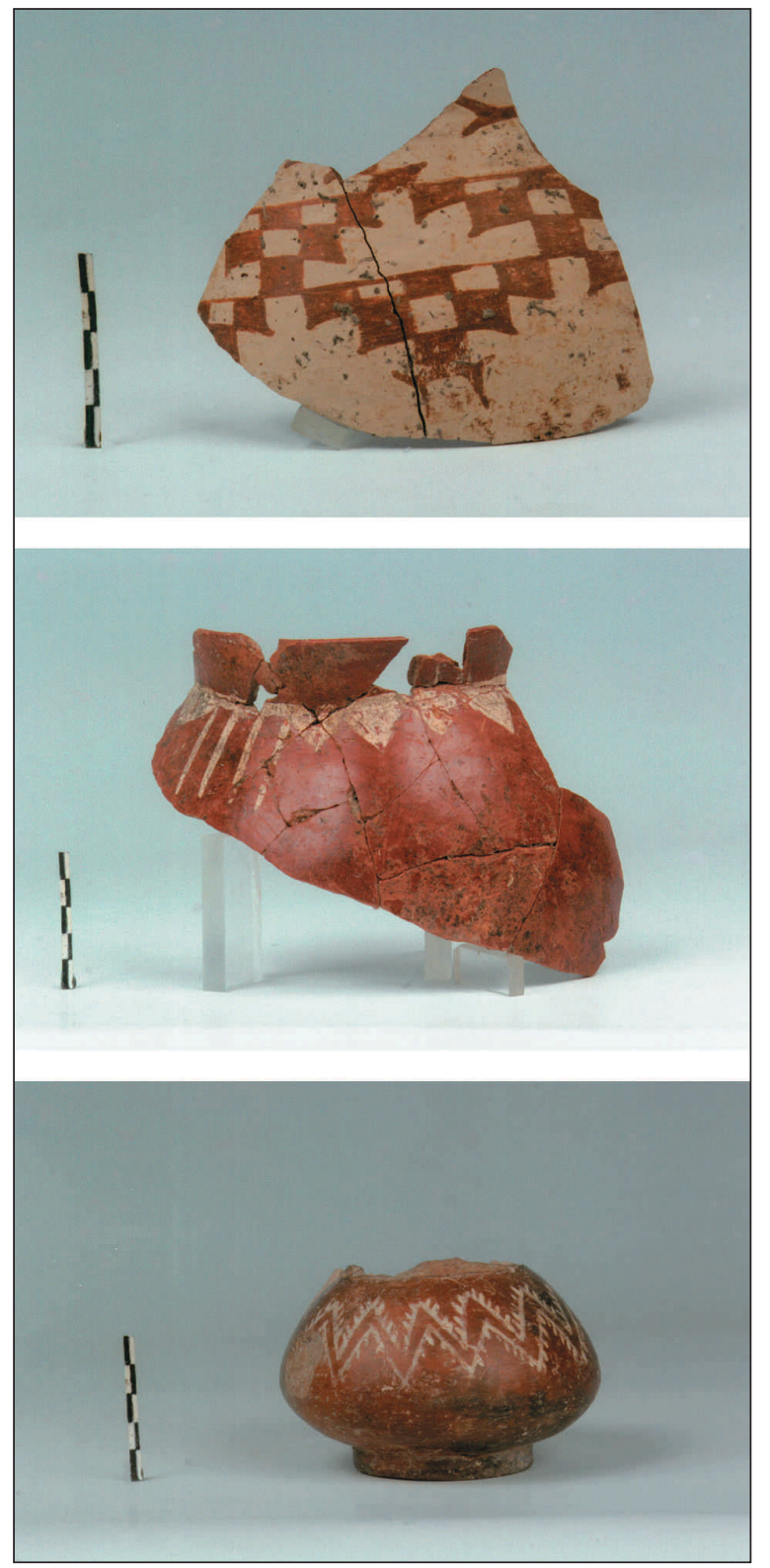




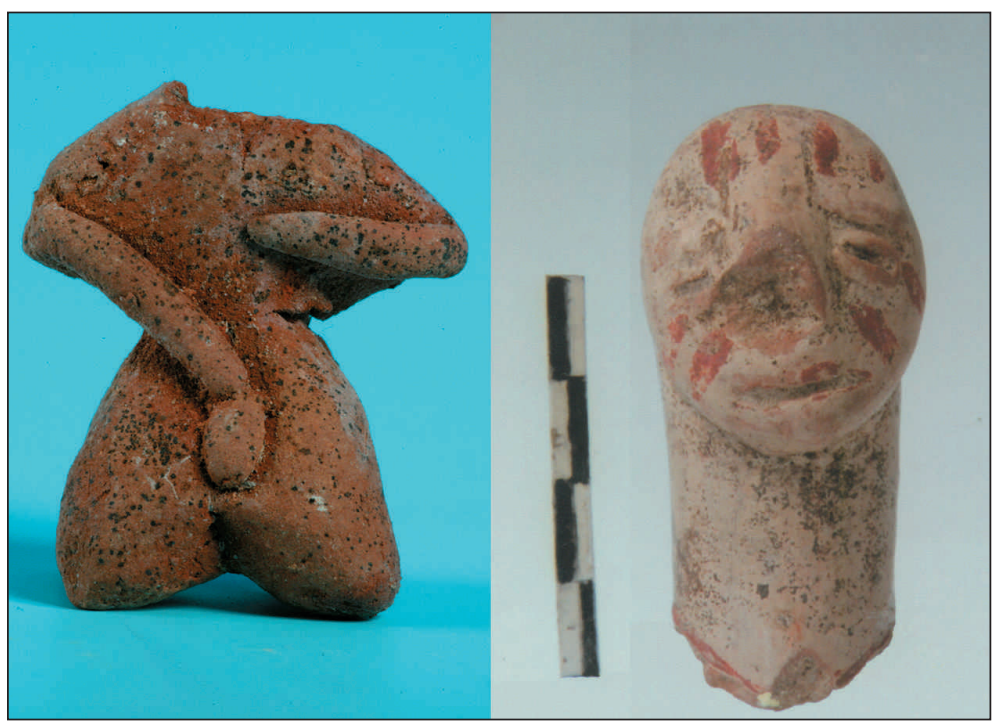

Fig. 14. A headless male figurine and the head of another (the latter with red on white painted decoration).
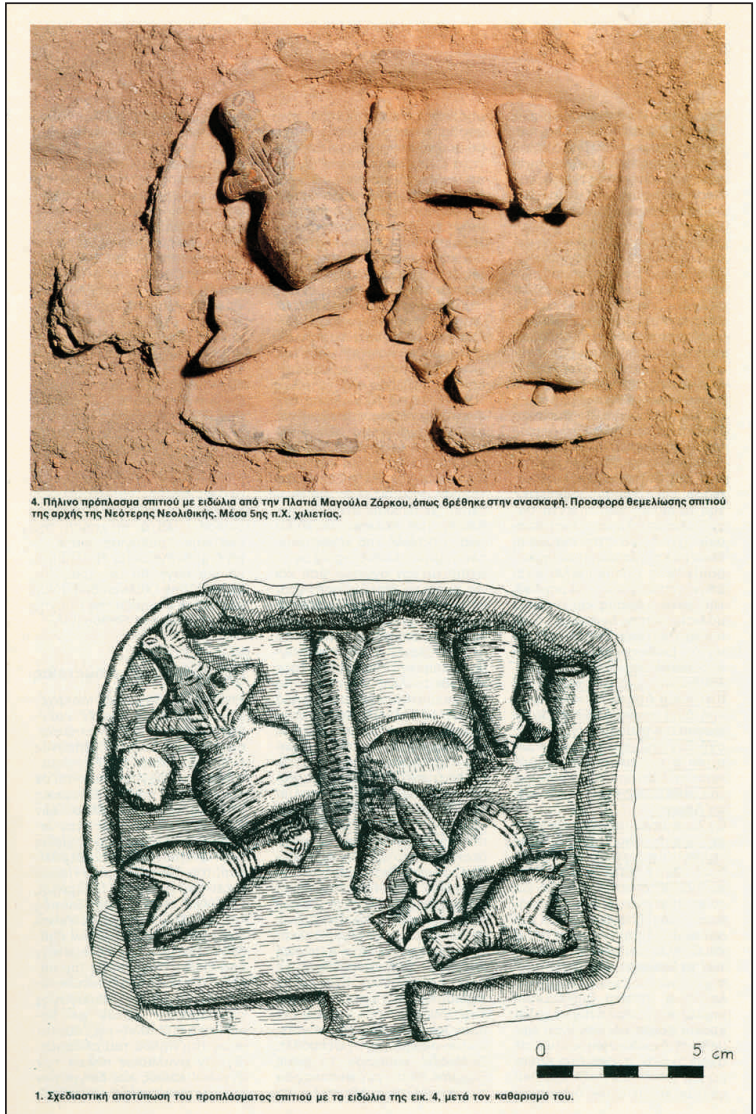

Fig. 15. The clay model of the interior of a Neolithic house found at Platia Magoula Zarkou. A food baking kiln is visible (after Gallis 1985).

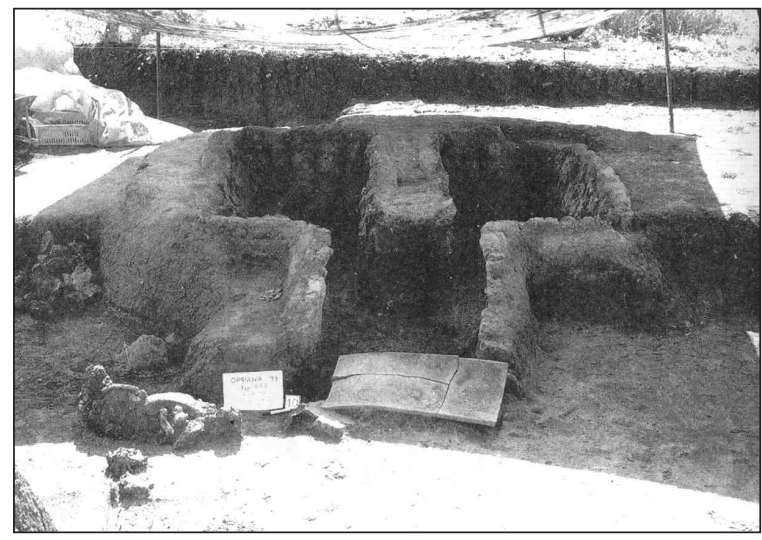

Fig. 16. A kiln of the Classical period (c. $5^{\text {th }}$ century B.C.) found at the village of Orfana, not far from Neo Monastiri and Imvrou Pigadi (after Rondiri 1999.275-289, Fig. 4).

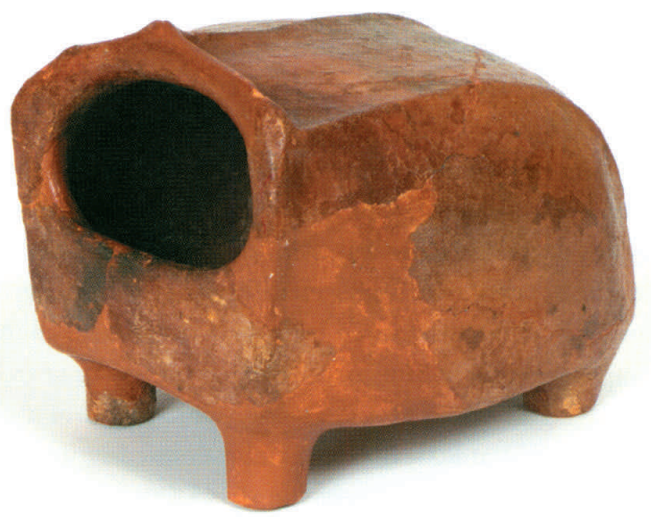

Fig. 17. The architectural model of Cucuteni culture (after Lazarovici 2010) that could possibly be compared to our kiln model. 